\title{
Pseudomonas cepacia sp. nov., nom. rev.
}

\author{
N. J. PALLERONI ${ }^{1}$ AND B. HOLMES ${ }^{2}$ \\ Chemical Research Department, Hoffmann-La Roche Inc., Nutley, New Jersey 07110' and National \\ Collection of Type Cultures, Central Public Health Laboratory, London NW9 5HT, United Kingdom ${ }^{2}$
}

The name Pseudomonas cepacia Burkholder was omitted from the Approved Lists of Bacterial Names and therefore lost standing in bacterial nomenclature. In this paper we revive this name; it is used for the same taxon to which it was originally applied by Burkholder. A description of the species and a comparison with other species of Pseudomonas ribonucleic acid homology group II are included. Since no type strain was chosen by Burkholder, strain ATCC 25416 is designated the type, following the suggestion of Ballard et al.

In this paper we revive the name Pseudomonas cepacia, which was previously validly published by Burkholder (2) for the causative agent of a bacterial rot of onion bulbs. The description of Burkholder was expanded considerably by Ballard et al. (1). The name lost its validity by being excluded from the Approved Lists of Bacterial Names (12). In accordance with Rule 28a of the International Code of Nomenclature of Bacteria (5), the name is here revived.

The following description of $P$. cepacia is based on the study of Ballard et al. (1), which included observations by Stanier et al. (14) on strains labeled Pseudomonas multivorans, which was found to be a synonym of $P$. cepacia $(1,11)$. The synonymy of "Pseudomonas kingii" Jonsson (4) (names in quotation marks are not on the Approved Lists of Bacterial Names [12] and have not been published validly since 1 January 1980; hence, they are without standing in bacterial nomenclature) with $P$. cepacia was established by Snell et al. (13).

Pseudomonas cepacia (ex Burkholder, 1950) nom. rev. ( $P$. multivorans Stanier et al., 1966; "P. kingii" Jonsson, 1970) (ce pa'ci a.L. fem.n. caepa or cepa onion; M.L. fem. adj. Cepacius of or like onion.)

Rods 0.8 to 1 by 1.6 to $3.2 \mu \mathrm{m}$. Cells occur singly or in pairs and are motile by means of a tuft of polar flagella. Cells accumulate poly-betahydroxybutyrate as a carbon reserve material, especially in nitrogen-deficient media.

Pigments which do not fluoresce under lowwavelength ultraviolet light $(254 \mathrm{~nm})$ are produced by most strains. On ordinary complex media, the pigmentation is yellow or greenish, but on chemically defined media the pigments may show a great variety of colors, depending on the carbon source used for growth. In some cases the pigments are associated with the cells, and in other cases they diffuse into the medium.

Denitrification is negative; nitrate is reduced to nitrite.
Lipolytic. Some strains hydrolyze gelatin, and some give a positive lecithinase (egg yolk) reaction.

No organic growth factors are required. $\mathrm{Nu}$ tritionally, the most versatile of the Pseudomo. nas species known to date. Out of about 150 organic compounds, one-third or more can be used as sole carbon and energy sources for growth $(1,14)$; these compounds include a large variety of carbohydrates, mono- and dicarboxylic acids, mono- and polyalcohols, aromatic compounds, amino acids, and amines. Substrates which are of diagnostic value and are used by the great majority of the strains but which are used only infrequently by strains of other Pseudomonas species include D-arabinose, D-fucose, cellobiose, saccharate, mucate, 2,3-butylene glycol, sebacate, meso-tartrate, citraconate, $\alpha$-hydroxybenzoate, $m$-hydroxybenzoate, L-threonine, DL-ornithine, and tryptamine. D-(-)-Tartrate, mesaconate, and erythritol are among the compounds not utilized for growth $(1,14)$. Only three strains originally labeled $P$. multivorans can use maltose for growth (14).

Obligately aerobic. Optimal growth temperature, 30 to $35^{\circ} \mathrm{C}$. No growth at $4^{\circ} \mathrm{C}$. Most strains grow at $41^{\circ} \mathrm{C}$, and almost all grow at $40^{\circ} \mathrm{C}$.

Strains have been isolated from rotten onions, soils, and various clinical specimens, including benzalkonium chloride solutions (3).

The average guanine-plus-cytosine content of the deoxyribonucleic acid is $67.4 \mathrm{~mol} \%$, as determined by buoyant density centrifugation. Deoxyribonucleic acid-deoxyribonucleic acid hybridization experiments have indicated that this species is related to Pseudomonas gladioli ("Pseudomonas marginata," "Pseudomonas alliicola"), Pseudomonas caryophylli, Pseudomonas mallei, and Pseudomonas pseudomallei (1; M. Rogul, J. Brendle, D. K. Haapala, and A. D. Alexander, Bacteriol. Proc., p. 19, 1968). In addition, ribosomal ribonucleic acid-deoxyribonucleic acid hybridization studies have shown a 
TABLE 1. Characters of diagnostic value in distinguishing P. cepacia from other species of Pseudomonas group $I I^{a}$

\begin{tabular}{|c|c|c|c|c|c|c|c|}
\hline Characteristic & $\begin{array}{c}\text { P. cepa- } \\
\text { cia } \\
\end{array}$ & P. gladioli & $\begin{array}{l}\text { P. cary. } \\
\text { ophylli }\end{array}$ & $\begin{array}{l}\text { P. pseu- } \\
\text { domallei }\end{array}$ & P. mallei & $\begin{array}{l}\text { P. solan- } \\
\text { acearum }\end{array}$ & P. pickettii \\
\hline Denitrification & $-{ }^{b}$ & - & + & + & $\mathrm{v}$ & + & + \\
\hline Arginine dihydrolase & - & - & + & + & + & - & - \\
\hline Hydrolysis of gelatin & $\mathrm{v}$ & + & - & + & + & - & - \\
\hline Hydrolysis of $\mathrm{PHB}^{\mathrm{c}}$ & - & - & - & + & $\mathrm{v}$ & - & - \\
\hline Hydrolysis of starch & - & - & - & + & $\mathbf{v}$ & - & - \\
\hline \multicolumn{8}{|l|}{ Utilization of: } \\
\hline L-Rhamnose & $\mathrm{v}$ & - & + & - & - & - & - \\
\hline Maltose, starch & $(-)$ & - & - & + & $\mathrm{v}$ & - & - \\
\hline Saccharate, mucate & + & + & + & - & - & + & + \\
\hline Malonate & + & + & + & - & $\mathrm{v}$ & - & + \\
\hline Glutarate & + & $\mathbf{v}$ & - & $\mathbf{v}$ & $\mathbf{v}$ & - & $v$ \\
\hline Adipate & + & + & - & + & + & - & + \\
\hline Azelate, sebacate & + & + & - & + & $\mathrm{v},-$ & $\mathrm{v}$ & + \\
\hline D-(-)-Tartrate & - & + & - & - & - & - & - \\
\hline Glycolate & $\mathrm{v}$ & - & + & - & - & $\mathrm{v}$ & + \\
\hline Hydroxymethylglutarate & + & + & + & + & - & - & + \\
\hline Aconitate & + & + & + & + & - & + & + \\
\hline Levulinate & + & - & - & + & - & $\mathrm{v}$ & + \\
\hline Citraconate & + & + & - & - & - & - & + \\
\hline Mesaconate & - & + & - & - & - & - & - \\
\hline Erythritol & - & - & - & + & - & - & - \\
\hline 2,3-Butylene glycol & + & - & + & - & - & - & $\mathbf{v}$ \\
\hline Benzoate & + & + & - & + & + & - & - \\
\hline D-Alanine & + & + & - & + & + & + & + \\
\hline L-Valine & $\mathrm{v}$ & + & $\mathrm{v}$ & + & $\mathrm{v}$ & - & + \\
\hline DL-alpha-Aminobutyrate & - & $\mathrm{v}$ & - & - & $\mathbf{v}$ & - & - \\
\hline delta-Aminovalerate & + & - & - & + & $\mathrm{v}$ & - & - \\
\hline Kynurenate, anthranilate & + &,$+ \mathrm{v}$ & - & + &,$- \mathrm{v}$ & - &,+- \\
\hline Ethanolamine & + & + & - & + & - & - & - \\
\hline Benzylamine & $\mathrm{v}$ & $(-)$ & - & - & - & - & - \\
\hline Putrescine & + & - & - & + & $\mathrm{v}$ & - & - \\
\hline Spermine & + & - & - & $\mathrm{v}$ & - & - & - \\
\hline Acetamide & $\mathbf{v}$ & - & - & - & - & - & - \\
\hline Nicotinate & $\mathrm{v}$ & + & - & - & - & - & - \\
\hline
\end{tabular}

${ }^{a}$ In addition, the guanine-plus-cytosine contents of the deoxyribonucleic acids are as follows: $P$. cepacia, 67.4 mol\%; P. gladioli, $68.5 \mathrm{~mol} \% ;$ P. caryophylli, $65.3 \mathrm{~mol} \% ; P$. pseudomallei, $69.5 \mathrm{~mol} \% ;$. mallei, $69 \mathrm{~mol} \% ; P$. solanacearum, 66.5 to $68 \mathrm{~mol} \%$; and $P$. pickettii, $64 \mathrm{~mol} \%$. The data in this table were taken from the following sources: $P$. cepacia (including $P$. multivorans strains), references 1 and $14 ; P$. gladioli (" $P$. marginata" and " $P$. alliicola") and $P$. caryophylli, reference $1 ; P$. mallei and $P$.pseudomallei, references 6 and $10 ; P$. solanacearum, reference $7 ; P$. pickettii, reference 9 .

${ }^{b}+$, Positive; - , negative; $(-)$, present in more than $90 \%$ of the strains; $v$, present in more than $10 \%$ but less than $90 \%$ of the strains.

${ }^{c}$ PHB, Poly- $\beta$-hydroxybutyrate.

relationship to Pseudomonas solanacearum and Pseudomonas pickettii (8). At present this species is included in Pseudomonas Group II (8). Table 1 lists characters of diagnostic value for the differentiation of $P$. cepacia from other species of this group.

Type strain: Burkholder (=717-ICPB 25, $=$ ATCC 25416, =NCTC 10743) (1). This strain has given the following results for the tests that are not universally positive or negative for the 37 strains of $P$. cepacia that have been characterized fully $(1,14)$ : it liquefies gelatin and gives a positive egg yolk reaction; it is able to grow on trehalose, butanol, glycolate, L-mandelate, benzoylformate, benzoate, testosterone, L-valine, $\mathrm{L}$ - leucine, delta-aminovalerate, butylamine, benzylamine, and acetamide; and it does not grow on L-rhamnose, maltose, starch, isobutanol or nicotinate. The guanine-plus-cytosine content of the deoxyribonucleic acid is $67.8 \mathrm{~mol} \%$.

\section{REPRINT REQUESTS}

Address reprint requests to: N. J. Palleroni, Chemical Research Department, Hoffmann-La Roche Inc., Nutley, NJ 07110 .

\section{LITERATURE CITED}

1. Ballard, R. W., N. J. Palleroni, M. Doudoroff, R. Y. Stanier, and M. Mandel. 1970. Taxonomy of the aerobic pseudomonads: Pseudomonas cepacia, P. margin- 
ata, P. alliicola and P. caryophylli. J. Gen. Microbiol. 60:199-214.

2. Burkholder, W. H. 1950. Sour skin, a bacterial rot of onion bulbs. Phytopathology 40:115-117.

3. Hardy, P. C., G. M. Ederer, and J. M. Matsen. 1970. Contamination of commercially packed urinary catheter kits with the pseudomonad EO-1. N. Engl. J. Med. 282:33-35.

4. Jonsson, V. 1970. Proposal of a new species, Pseudomonas kingii. Int. J. Syst. Bacteriol. 20:255-257.

5. Lapage, S. P., P. H. A. Sneath, E. F. Lessel, V. B. D. Skerman, H. P. R. Seeliger, and W. A. Clark (ed.). 1975. International code of nomenclature of bacteria. 1975 Revision. American Society for Microbiology, Washington, D.C.

6. Mandel, M. 1966. Deoxyribonucleic acid base composition in the genus Pseudomonas. J. Gen. Microbiol. 43:273292.

7. Palleroni, N. J., and M. Doudoroff. 1971. Phenotypic characterization and deoxyribonucleic acid homologies of Pseudomonas solanacearum. J. Bacteriol. 107:690696.

8. Palleroni, N. J., R. Kunisawa, R. Contopoulou, and
M. Doudoroff. 1973. Nucleic acid homologies in the genus Pseudomonas. Int. J. Syst. Bacteriol. 23:333-339.

9. Ralston, E., N. J. Palleroni, and M. Doudoroff. 1973. Pseudomonas pickettii, a new species of clinical origin related to Pseudomonas solanacearum. Int. J. Syst. Bacteriol. 23:15-19.

10. Redfearn, M. S., N. J. Palleroni, and R. Y. Stanier. 1966. A comparative study of Pseudomonas pseudom. allei and Bacillus mallei. J. Gen. Microbiol. 43:293313.

11. Sands, D. C., M. N. Schroth, and D. C. Hildebrand. 1970. Taxonomy of phytopathogenic pseudomonads. J. Bacteriol. 101:9-23.

12. Skerman, V. B. D., V. McGowan, and P. H. A. Sneath (ed.). 1980. Approved lists of bacterial names. Int. J. Syst. Bacteriol. 30:225-420.

13. Snell, J. J. S., L. R. Hill, S. P. Lapage, and M. A. Curtis. 1972. Identification of Pseudomonas cepacia Burkholder and its synonymy with Pseudomonas kingii Jonson. Int. J. Syst. Bacteriol. 22:127-138.

14. Stanier, R. Y., N. J. Palleroni, and M. Doudoroff. 1966. The aerobic pseudomonads: a taxonomic study. J. Gen. Microbiol. 43:159-271. 